\begin{tabular}{|c|c|c|}
\hline Case Reports in & \multicolumn{2}{|c|}{ Case Rep Gastroenterol 2014;8:175-181 } \\
\hline Gastroenterology & $\begin{array}{l}\text { DOI: 10.1159/000363373 } \\
\text { Publisned ontine: IVlay } 15,2014\end{array}$ & $\begin{array}{l}\text { (c) } 2014 \text { S. Karger AG, Basel } \\
1662-0631 / 14 / 0082-0175 \$ 39.50 / 0 \\
\text { www.karger.com/crg }\end{array}$ \\
\hline & \multicolumn{2}{|c|}{$\begin{array}{l}\text { This is an Open Access article licensed under the terms of the Creative Commons } \\
\text { Attribution-NonCommercial } 3.0 \text { Unported license (CC BY-NC) (www.karger.com/OA } \\
\text { license), applicable to the online version of the article only. Distribution permitted for non } \\
\text { commercial purposes only. }\end{array}$} \\
\hline
\end{tabular}

\title{
Spontaneous Colon Perforations Associated with a Vascular Type of Ehlers-Danlos Syndrome
}

\author{
Akira Yoneda $^{a} \quad K^{2}$ azuya Okada ${ }^{a}$ Hitoshi Okubo $^{a}$ Mitsutoshi Matsuo ${ }^{a}$ \\ Hiroki Kishikawa $^{a} \quad$ Banyar Than Naing $^{b}$ Atsushi Watanabe ${ }^{b}$ \\ Takashi Shimada ${ }^{\text {b }}$ \\ ${ }^{a}$ Department of Surgery, Kouseikai Hospital, Nagasaki, and ${ }^{b}$ Department of Biochemistry \\ and Molecular Biology, Nippon Medical School, Tokyo, Japan
}

\section{Key Words}

Spontaneous colonic perforations · Ehlers-Danlos syndrome · Connective tissue

\begin{abstract}
Ehlers-Danlos syndrome, vascular type (vEDS) (MIM \#130050) is an autosomal dominant disorder caused by mutation in the type III collagen gene, COL3A1, leading to fragility of blood vessels, bowel and uterus that leads to spontaneous rupture. We report a previously undiagnosed vEDS patient with bowel complications. A 20-year-old female patient was referred to our hospital with abdominal pain. Computed tomography showed notable dilatation of the sigmoid colon with intraperitoneal fluid. Laparotomy revealed dilatation of the sigmoid colon, breakdown of serosa and muscularis propria of the sigmoid colon with impending perforation, and intra-abdominal hemorrhage caused by breakdown of the mesenterium. Resection of the sigmoid colon with Hartmann's pouch and an end colostomy were performed. Physical examination showed joint hypermobility, translucent skin with venous prominence and facial structure abnormalities. Genetic analysis using cDNA extracted from the patient's fibroblasts by reverse transcriptase polymerase chain reaction direct sequencing showed a missense mutation within the triple helix region of COL3A1 (c.2150 G>A; Gly717Asp).


Yoneda et al.: Spontaneous Colon Perforations Associated with a Vascular Type of Ehlers-Danlos Syndrome

\section{Introduction}

Ehlers-Danlos syndrome (EDS) is a clinically, genetically and biochemically heterogeneous group of inherited connective tissue disorders. The major manifestations of EDS are skin fragility, skin hyperextensibility and joint hypermobility $[1,2]$. The disorder was first reported in 1668 [3], but it was not until the early 1900s that the characteristics of the syndrome were described by Ehlers [4] and Danlos [5]. Six types of EDS have been described on the basis of clinical, genetic and/or biochemical differences [6]. EDS is now considered a heterogeneous group of disorders, the most lethal of which is the vascular type (vEDS), formerly called type IV EDS (MIM \#130050) [7]. It is caused mainly by glycine substitution mutation in the triple helix region of the type III collagen gene (COL3A1: MIM \#120180), leading to extreme fragility of blood vessels, bowel and uterus and thus leading to spontaneous rupture [8]. The following is an account of a previously undiagnosed vEDS patient with bowel complications who was managed at our institution.

\section{Case Report}

A 20-year-old female patient was referred to our hospital with abdominal pain, nausea and vomiting. Physical examination revealed mild hypotension and a distended, tender abdomen. Her vital signs were a temperature of $37.9^{\circ} \mathrm{C}$, a heart rate of 98 beats per minute and a blood pressure of $97 / 49 \mathrm{~mm} \mathrm{Hg}$. Laboratory studies found a white blood cell count of $12,250 / \mathrm{mm}^{3}$. A computed tomography scan showed notable dilatation of the sigmoid colon with intraperitoneal fluid (fig. 1). An emergent laparotomy revealed dilatation of the sigmoid colon, breakdown of the serosa and muscularis propria of the sigmoid colon with impending perforation, and intra-abdominal hemorrhage caused by breakdown of the mesenterium of the sigmoid colon (fig. 2). As the rest of the intestine was normal, resection of the sigmoid colon with Hartmann's pouch and an end colostomy were performed. The macroscopic appearance of the resected colon showed strong alteration of the bowel wall, with some areas showing a complete lack of the lamina muscularis propria (fig. 3a). Histological findings of the resected specimen showed mucosal necrosis with leukocytic infiltration (fig. $3 b$ ). The postoperative course was uneventful, and the patient was discharged from the hospital 1 month after entry. Careful physical examination showed joint hypermobility, translucent skin with venous prominence and facial structure abnormalities (crooked nose and large eyes). Because of the uncommon intraoperative and clinical findings, there was a high suspicion of connective tissue disorder. Genetic analysis using cDNA extracted from the patient's fibroblasts by a reverse transcriptase polymerase chain reaction direct sequencing method showed a nucleotide change at c.2150 G>A on exon 32 (GenBank ID: NM_000090.3) as the reference. This nucleotide change resulted in the amino acid change of glycine at position 717 to aspartate within the triple helix region of COL3A1 (Gly717Asp), which confirmed a diagnosis of vEDS (fig. 4). No specific therapy has been shown to delay or prevent further complications. Lifelong close follow-up should be continued in this patient.

\section{Discussion}

EDS comprises a group of hereditary connective tissue disorders with different genetic backgrounds and heterogeneous clinical features. The overall incidence is 1 in 150,000 [6]. Common to all of these types is an underlying defect in either collagen production or 
Yoneda et al.: Spontaneous Colon Perforations Associated with a Vascular Type of Ehlers-Danlos Syndrome

processing. Though uncommon, vEDS is the most severe type. It accounts for 3-6\% of all EDS cases [9]. The disease is caused by heterozygous germline mutations in the type III procollagen gene (COL3A1) [10-13]. The diagnosis of vEDS depends on the combination of clinical manifestations, family history and the demonstration of collagen type III qualitative and/or quantitative defects. As type III collagen is most abundant in vessels and hollow organ soft tissue, defects in type III collagen production result in vascular and hollow organ complications [14]. The clinical features of vEDS include prematurity, low birth weight, congenital dislocation of the hips, club feet, easy bruising, thin and translucent skin displaying prominent venous patterns, hypermobility of small joints, constipation, arterial aneurysms and ruptures, spontaneous pneumothorax and colonic perforations [15].

Since skin and joint manifestations are less prominent than in the other types of EDS, the diagnosis of vEDS often is missed until the patient presents with a major complication such as spontaneous arterial or bowel rupture [16]. The first complication occurs by age 20 in $25 \%$ of cases, and in $80 \%$ of cases by age 40 [16]. As the most common complications of the disease are in the gastrointestinal tract and vascular systems, surgical approaches are troublesome for surgical teams [17]. Early diagnosis of peritonitis is critical so that an appropriate therapy can be instituted expeditiously, including correction of fluid and electrolyte abnormalities, institution of antibiotic therapy and surgical repair of the underlying lesion [18]. As the tissues are extremely fragile, it is essential to avoid invasive techniques. Sutures tend to tear them out, bowel walls are extremely friable and anastomosis is arduous. Small vessels are equally fragile, occasioning difficult hemostasis, oozing and hematoma formation [19-21].

Although spontaneous bowel perforation has been reported in the literature with more than 50 cases documented, the surgical management and outcomes of this manifestation of vEDS have varied considerably. In a retrospective review of the literature, 41 colonic perforations were reported, $80 \%$ of which were in the sigmoid colon. Of these patients, $66 \%$ were treated with resection and diversion, with 18 eventually undergoing restoration of intestinal continuity. A total of $55.6 \%$ of these patients suffered a re-perforation, some with three or four perforations. Eleven patients underwent total abdominal colectomy, 7 with ileoproctostomy [22]. The treatment of bowel perforation in these patients is controversial. Different surgical procedures have been advocated, but there is no large serial study currently available to demonstrate the superiority of any one option.

Women with vEDS have an increased risk of complications of pregnancy as well as a $50 \%$ risk of having an affected child [14]. Major complications of pregnancy can occur in the antenatal period, during labor and delivery, and postpartum. A maternal mortality of up to $25 \%$ has been reported due to rupture of the artery, bowel or uterus [1]. The complications of pregnancy include rupture of the bowel, aorta, vena cava or uterus, vaginal laceration, postpartum uterine hemorrhage, varicose veins, uterine and/or bladder prolapse, joint laxity, abdominal herniation and wound dehiscence [23]. These patients who become pregnant should be considered at high risk and should receive regular follow-up at specialized centers.

No specific therapy has been shown to delay or prevent further complications [24], and the long-term natural history of this anatomy in vEDS is confrontational. However, knowledge of the disease can influence surgical procedures and genetic counseling. Lifelong close follow-up should be continued in these patients. 


\begin{tabular}{l|l}
\hline Case Rep Gastroenterol 2014;8:175-181 \\
\hline DOI: $10.1159 / 000363373$ & $\begin{array}{l}\text { C 2014 S. Karger AG, Basel } \\
\text { www.karger.com/crg }\end{array}$ \\
\hline
\end{tabular}

Yoneda et al.: Spontaneous Colon Perforations Associated with a Vascular Type of Ehlers-Danlos Syndrome

\section{Disclosure Statement}

Akira Yoneda has no conflict of interest.

\section{Author Contributions}

Kazuya Okada, Hitoshi Okubo, Mitsutoshi Matsuo and Hiroki Kishikawa contributed equally to this work; Banyar Than Naing, Atsushi Watanabe and Takashi Shimada contributed new analytic tools; Akira Yoneda wrote the paper.

\section{References}

$\rightarrow 1$ Rudd NL, Nimrod C, Holbrook KA, Byers PH: Pregnancy complications in type IV Ehlers-Danlos syndrome. Lancet 1983;1:50-53.

2 Byers PH: Ehlers-Danlos syndrome: recent advances and current understanding of the clinical and genetic heterogeneity. J Invest Dermatol 1994;103(5 suppl):47S-52S.

3 van Meek'ren J: Heel-engeneeskonstige aamnerkkingen. Amsterdam, 1668, 170-2.

4 Ehlers E: Cutis laxa. Neigung zu Haemorrhagien in der Haut, Lockerung mehrerer Artikulationen. Dermatol Z 1901;8:173-174.

5 Danlos H: Un cas de cutis laxa avec tumeurs par contusion chronique des coudes et des genoux. Bull Soc Derm Syph 1908;19:70-72.

-6 Beighton P, De Paepe A, Steinmann B, Tsipouras P, Wenstrup RJ: Ehlers-Danlos syndrome: revised nosology. Am J Med Genet 1998;77:31-37.

$\checkmark 7$ Brees CK, Gall SA: Rupture of the external iliac artery during pregnancy: a case of type IV Ehlers-Danlos syndrome. J Ky Med Assoc 1995;93:553-555.

$\checkmark 8$ Barabas AP: Heterogeneity of the Ehlers-Danlos syndrome: description of three clinical types and a hypothesis to explain the basic defect(s). Br Med J 1967;2:612-613.

-9 Demirogullari B, Karabulut R, Demirtola A, Karabulut B, Gol IH, Aybay C, Symoens S, Sonmez K, Basaklar AC, Kale N: A novel mutation in the vascular Ehlers-Danlos syndrome: a case presenting with colonic perforations. J Pediatr Surg 2006;41:e27-e30.

10 Pope FM, Martin GR, Lichtenstein JR, Penttinen R, Gerson B, Rowe DW, McKusick VA: Patients with EhlersDanlos syndrome type IV lack type III collagen. Proc Natl Acad Sci USA 1975;72:1314-1316.

11 Superti-Furga A, Steinmann B: Impaired secretion of type III procollagen in Ehlers-Danlos syndrome type IV fibroblasts: correction of the defect by incubation at reduced temperature and demonstration of subtle alterations in the triple-helical region of the molecule. Biochem Biophys Res Commun 1988;150:140-147.

12 Superti-Furga A, Gugler E, Gitzelmann R, Steinmann B: Ehlers-Danlos syndrome type IV: a multi-exon deletion in one of the two COL3A1 alleles affecting structure, stability, and processing of type III procollagen. J Biol Chem 1988;263:6226-6232.

13 Naing BT, Watanabe A, Shimada T: A novel mutation screening system for Ehlers-Danlos syndrome, vascular type by high-resolution melting curve analysis in combination with small amplicon genotyping using genomic DNA. Biochem Biophys Res Commun 2011;405:368-372.

14 Pepin M, Schwarze U, Superti-Furga A, Byers PH: Clinical and genetic features of Ehlers-Danlos syndrome type IV, the vascular type. N Engl J Med 2000;342:673-680.

15 Pope FM, Narcisi P, Nicholls AC, Liberman M, Oorthuys JW: Clinical presentations of Ehlers Danlos syndrome type IV. Arch Dis Child 1988;63:1016-1025.

-16 Fuchs JR, Fishman SJ: Management of spontaneous colonic perforation in Ehlers-Danlos syndrome type IV. J Pediatr Surg 2004;39:e1-e3.

17 Oderich GS, Panneton JM, Bower TC, Lindor NM, Cherry KJ, Noel AA, Kalra M, Sullivan T, Gloviczki P: The spectrum, management and clinical outcome of Ehlers-Danlos syndrome type IV: a 30-year experience. J Vasc Surg 2005;42:98-106.

18 Kinnane J, Priebe C, Caty M, Kuppermann N: Perforation of the colon in an adolescent girl. Pediatr Emerg Care 1995;11:230-232.

19 Berney T, La Scala G, Vettorel D, Gumowski D, Hauser C, Frileux P, Ambrosetti P, Rohner A: Surgical pitfalls in a patient with type IV Ehlers-Danlos syndrome and spontaneous colonic rupture. Report of a case. Dis Colon Rectum 1994;37:1038-1042.

20 Soucy P, Eidus L, Keeley F: Perforation of the colon in a 15-year-old girl with Ehlers-Danlos syndrome type IV. J Pediatr Surg 1990;25:1180-1182. 


\begin{tabular}{l|l}
\hline Case Rep Gastroenterol 2014;8:175-181 \\
\hline DOI: $10.1159 / 000363373$ & $\begin{array}{l}\text { @ 2014 S. Karger AG, Basel } \\
\text { www.karger.com/crg }\end{array}$ \\
\hline
\end{tabular}

Yoneda et al:: Spontaneous Colon Perforations Associated with a Vascular Type of Ehlers-Danlos Syndrome

21 Omori H, Hatamochi A, Koike M, Sato Y, Kosho T, Kitakado Y, Oe T, Mukai T, Hari Y, Takahashi Y, Takubo K: Sigmoid colon perforation induced by the vascular type of Ehlers-Danlos syndrome: report of a case. Surg Today 2011;41:733-736.

22 Freeman RK, Swegle J, Sise MJ: The surgical complications of Ehlers-Danlos syndrome. Am Surg 1996;62:869-873.

23 Wood J: Care study: pregnancy and Ehlers-Danlos syndrome type IV. Midwives Chron 1993;106:446-448.

-24 Ong KT, Perdu J, De Backer J, Bozec E, Collignon P, Emmerich J, Fauret AL, Fiessinger JN, Germain DP,

Georgesco G, Hulot JS, De Paepe A, Plauchu H, Jeunemaitre X, Laurent S, Boutouyrie P: Effect of celiprolol on prevention of cardiovascular events in vascular Ehlers-Danlos syndrome: a prospective randomised, open, blinded-endpoints trial. Lancet 2010;376:1476-1484.

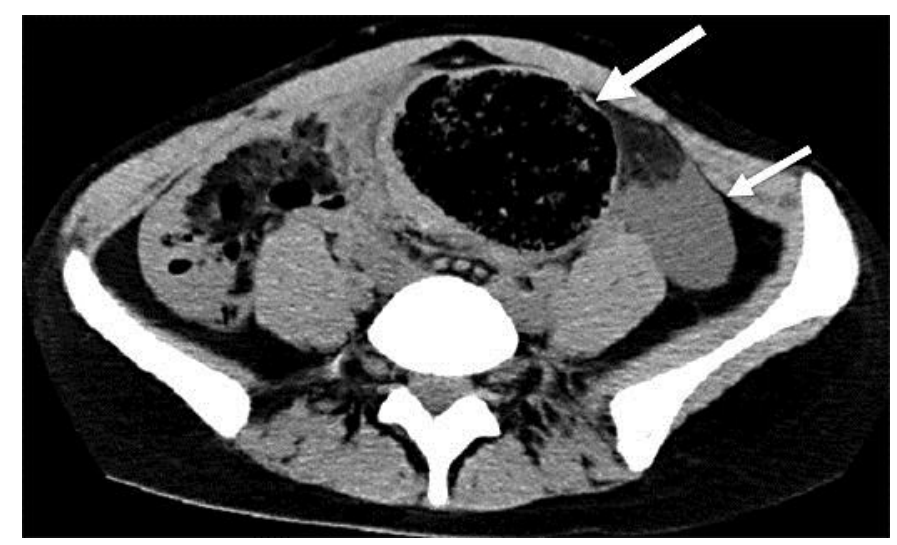

Fig. 1. Computed tomography scan of the abdomen displayed notable dilatation of the sigmoid colon (large arrow) with intraperitoneal fluid (small arrow).

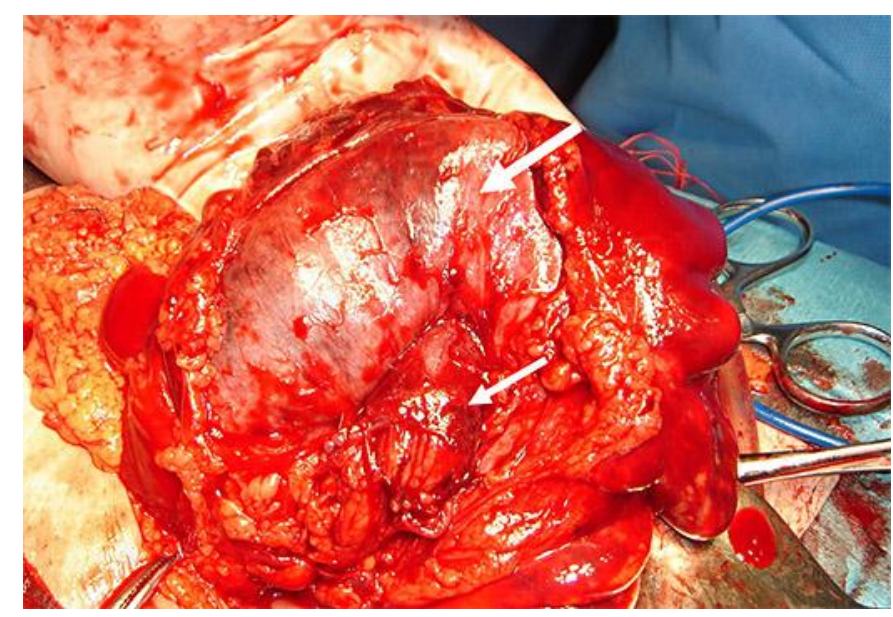

Fig. 2. Operative findings showed dilatation of the sigmoid colon, breakdown of serosa and muscularis propria of the sigmoid colon with impending perforation (large arrow), and intra-abdominal hemorrhage caused by breakdown of the mesenterium of the sigmoid colon (small arrow). 


\begin{tabular}{|c|c|c|}
\hline \multirow{3}{*}{$\begin{array}{r}\text { Case Reports in } \\
\text { Gastroenterology }\end{array}$} & \multirow{2}{*}{\multicolumn{2}{|c|}{ Case Rep Gastroenterol 2014;8:175-181 }} \\
\hline & & \\
\hline & DOI: 10.1159/000363373 & $\begin{array}{l}\text { (c) } 2014 \text { S. Karger AG, Base } \\
\text { www.karger.com/crg }\end{array}$ \\
\hline
\end{tabular}
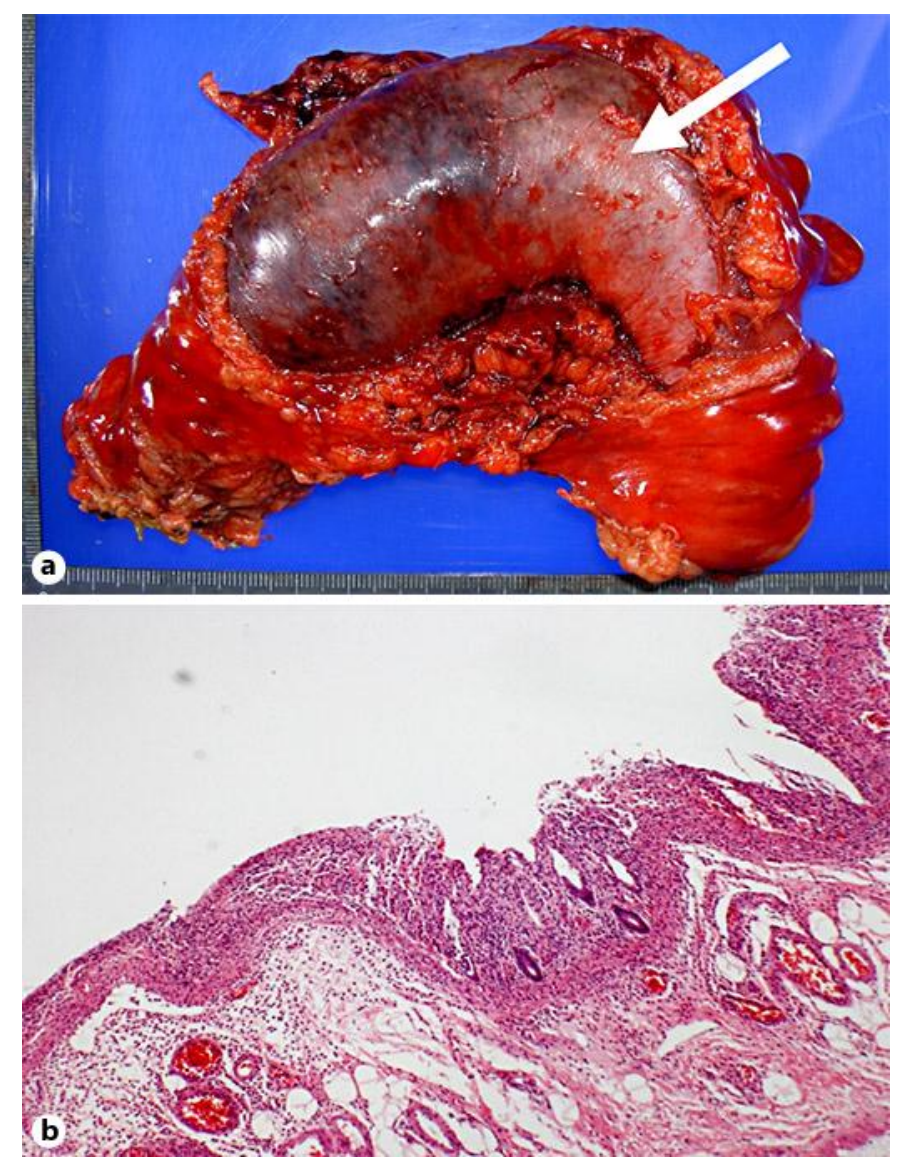

Fig. 3. a Macroscopic appearance of the resected colon. The architecture of the bowel wall is strongly altered, with some areas showing a complete lack of the lamina muscularis propria (arrow). b Histological findings of the resected specimen showed mucosal necrosis with leukocytic infiltration $(\mathrm{HE}, \times 100)$. 


\section{Case Reports in \\ Gastroenterology}

Control (COL3A1 CDNA)

Patient (COL3A1 CDNA)

\begin{tabular}{l|l}
\hline Case Rep Gastroenterol 2014;8:175-181 \\
\hline DOI: 10.1159/000363373 & $\begin{array}{l}\text { ○ 2014 S. Karger AG, Basel } \\
\text { www.karger.com/crg }\end{array}$ \\
\hline
\end{tabular}

Yoneda et al.: Spontaneous Colon Perforations Associated with a Vascular Type of Ehlers-Danlos Syndrome
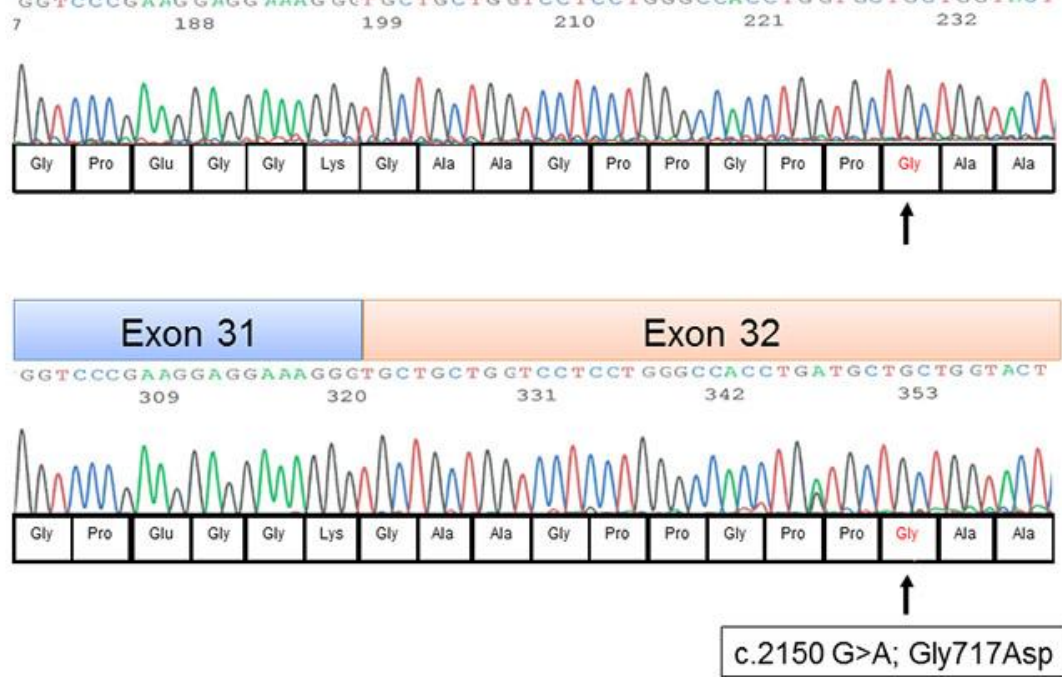

Fig. 4. COL3A1 gene mutation detected using cDNA extracted from the patient's fibroblasts. A heterozygous mutation was found within exon 32 of the COL3A1 gene at c.2150 G>A, leading to Gly717Asp (arrow) (GenBank ID: NM_000090.3 as the reference). 